\title{
Remittance Status and Contribution to GDP of Nepal
}

\author{
Krishna Prasad Ojha, MPhil \\ Lecturer \\ Nepal Commerce Campus, T.U.
}

\begin{abstract}
The research paper aims to analyze the status of remittance and its contribution to GDP of Nepal. The study has adopted the descriptive and analytical research design. The study is quantitative in nature. Most of the developing countries like Nepal depend on remittance as the major source of foreign currency earning. Remittance plays an important role in economic development of a country. Nepal has also long history of international labor migration about 200 years ago Nepali migrant laborers are contributing substantial amount as remittance inflows through legal channel which has positive impact on GDP, per-capita income, Capital formation, education etc. The volume of remittance is much more than the records because, migrants are using illegal ways due to ignorance and difficulty in receiving amount from legal ways.
\end{abstract}

Key words: Remittance, GDP, economy, inflow, migration.

\section{Introduction}

Most of the developing countries are becoming more progressively reliant on remittances. It has played an important role to economic growth and development in those countries. When the recipient economy undergoes an economic recession following crisis, natural calamity, or political conflict, remittances be likely to be constant and increase (Yang, 2008).

Migrant remittances are a significant and vital financial source for labor exporting countries, therefore the issue of their effects is of utmost importance. Indeed, it is almost becoming a substitute for foreign direct investment (FDI), official development assistance (ODA), debt relief or other public sources of finance development. These remittances were indeed more that 5 percent of the gross domestic product (GDP) in the developing countries and almost at par with foreign direct investment (WB, 2011). More importantly, it has also helped improve the balance of payment situation to some extent. Apart from providing financial liquidity to the system, remittance has provided the much needed impetus to development activities. Remittances contribute substantially to maintain macroeconomic stability. It permits the households to increase their consumption level, enables better health care, nutrition, housing and education (WB, 2005).

Nepal has also long history of international labour migration about 200 years ago. In $19^{\text {th }}$ century, for instance, the first men migrated to Lahore (in today's Pakistan) to join the army of Sikh ruler, Ranjit Sing and later in British force since 1815-16. With the entrance of globalization and liberalization, most of the youths of Nepal begin to migrate year on year for foreign employment in the recent decades because of economic plus non-economic causes (Bhatta, 2013). Many workforce regard abroad employment as their only viable option as there exists political havoc in the country. As a result, 250,000 people on an average leave the country annually in search of employment opportunities since 2007 (Ministry of Finance, 2011).

IMF, (2009) explained that remittances denote household income from foreign economies arising mainly from the temporary or permanent movement of people to those economies. Remittances include 
cash and non cash items that flow through legal channels, such as via electronic wire or through informal channel, such as money or goods carried across borders. They largely consist of funds and noncash times sent or given by individual, who have migrated to a new economy and become resident there, and the net compensation of boarder, seasonal, or other short-term workers who are employed in an economy in which they are not resident.

Moreover, the inflow of foreign remittances can make effective contribute to develop the financing capacities of the financial system, particularly in banking sector. Many studies showed that the enhancing of financial system in developing or emerging countries is an important factor of growth. In the case of several countries the surge of the remittances involves a liquidity increasing of the banks, a point which can be considered that if banks use these funds to lend more easily credits to small and medium-sized enterprises. However, banks would prefer to buy treasury bonds in spite of financing small private companies (Yaseen, 2012). The fact that this effect is more or less obvious according to the degree of financial development has been reached in the country.

\section{Objectives}

The major purpose of the study is to analyze the impact of remittance on Nepalese economy. And the specific objectives are:

i. To analyze remittance status and contribution to GDP in Nepal.

i. To assess the impact of remittance to per-capita income.

\section{Conceptual Framework}

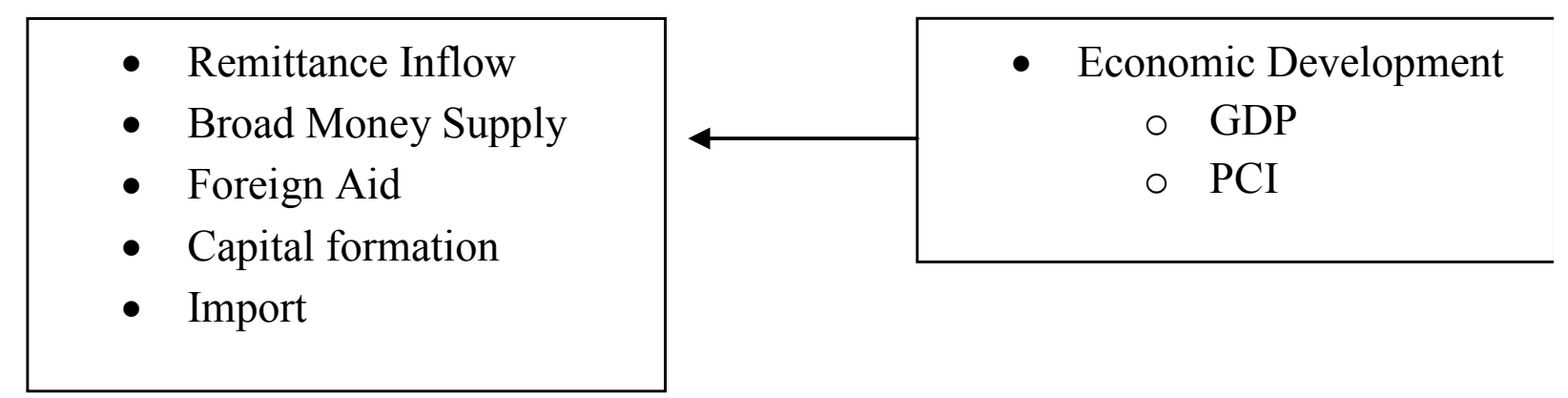

Figure 1 Conceptual Framework

Figure 1 has explained about conceptual framework of the study. The dependent variable is economic development measured in terms of GDP and PCI. The independent variables are remittance inflow, broad money supply, foreign aid, capital formation and import.

Literature Review 
Vol. 4 , No. 1

Table 1 Review of major literature (2011 onwards)

\begin{tabular}{ll}
\hline \multicolumn{1}{c}{ Study } & \multicolumn{1}{c}{ Major findings } \\
\hline Khan (2011) & $\begin{array}{l}\text { The finding of the study indicates that worker remittances have } \\
\text { significant and positive effects on economic growth. } \\
\text { The results suggested that remittances lead to increase in financial } \\
\text { Cooray (2012) }\end{array}$ \\
Sawaid \&Raza (2012) & $\begin{array}{l}\text { The study showed that the worker's remittance is more contributing in } \\
\text { high income countries as compared to low and middle income countries. }\end{array}$ \\
Khathlan (2012) & $\begin{array}{l}\text { The results showed a positive and significant relationship between } \\
\text { worker remittances and economic growth in both the long-run and the } \\
\text { short-run. } \\
\text { She finding of the research indicated that foreign remittances are } \\
\text { the famous mean of economic growth and have significant positive } \\
\text { relationship with each other. }\end{array}$
\end{tabular}

Salahuddin \& Gow (2015)

The study concluded that remittance are playing increasingly important role for economic growth.

Aggarwal et al.(2011) The findings show that remittance inflows are positively related to the measures of financial development. He also found the coefficient which is larger for the bank-deposit-to-GDP ratio than that of bank credit to GDP.

Anzoategui et al. The study found out that remittance inflow has a positive effect on (2011) financial inclusion by promoting the use of deposit accounts and remittance inflow do not has a significant effect on credit from formal financing.

Ahmed \& Martinez- $\quad$ Remittance inflow is found to be a less volatile source of external finance Zarzoso(2013) than FDI and Official development assistance (ODA) that are countercyclical and stabilizing, thus serving to steady the recipient economy in times of economic downturns.

Imai et al.(2011) The study found a positive relationship between workers' remittances and economic growth but the volatility of workers' remittances was found harmful for economic growth.

Table 2 Review of Nepali literature

\begin{tabular}{|c|c|}
\hline Study & Major findings \\
\hline $\begin{array}{l}\text { Thagunna \& Acharya } \\
\text { (2013) }\end{array}$ & $\begin{array}{l}\text { The finding of this study shows that remittance income and grants } \\
\text { appear to be the most relevant variables to raise nominal GDP in Nepal. } \\
\text { Pension and other items have also significant effect on increasing } \\
\text { nominal GDP in Nepal }\end{array}$ \\
\hline Pant (2011) & $\begin{array}{l}\text { The study concluded that remittances contribute largely to the national } \\
\text { economy. The remittances affect development at both the household } \\
\text { and national levels. }\end{array}$ \\
\hline
\end{tabular}


Gaudel (2006)

Pradhanet al., (2008)

Kollmairet al., (2006)

Srivastava \& chaudary (2007)

Kafle (2014)

Malekoo (2015)

Neupane (2011)

Shrestha (2008)
The finding of this study shows that remittance income and grants appear to be the most relevant variables to raise nominal GDP in Nepal. Pension and other items have also significant effect on increasing nominal GDP in Nepal

This study found that remittances have a positive impact on growth

The study concluded that labor migration and remittances is an important mainstay of Nepal's economy.

The finding of this study showed that remittance has not been used effectively so as to increase the real growth rates of the economy.

Remittance inflows are positively related with broad money supply but lag of total remittance inflow has more significant impact on broad money supply compared to total remittance inflow of current year

Remittance inflow has positive and significant effect on gross domestic product and total deposit of commercial banks'. The study also finds that consumption and gross capital formations have positive and significant impact on gross domestic product of the country.

The study stated that remittance is significant not only to increase domestic consumption expenditure but also to enhance GDP in the nation. However, remittance has reduced the domestic investment in the nation since large portion of remittance has been used upon the unproductive sector.

The study stated that remittances sent by the migrant workers are an effective tool for poverty reduction.

\section{Research Methods}

The study is based on secondary data collected from NRB reports and World Bank Reports of the sample firms recorded in the database provided in their respective websites. The secondary data has been employed in order to analyze the relationship, cause and effects associations between remittance and other macroeconomic variables. The sets of data for macro-economic variables have been collected for each year from 1994/95 to 2016/17. Regression model is also used to analyze the impact of remittance inflow on economy by computing regression equation for different samples. The relationship between dependent and independent variable can be stated in the following form:

Gross domestic product $=\mathrm{f}(\mathrm{REM}, \mathrm{CF}, \mathrm{IMP}, \mathrm{MS}, \mathrm{FA})$

Per capita income $=\quad \mathrm{f}(\mathrm{REM}, \mathrm{CF}, \mathrm{IMP}, \mathrm{MS}, \mathrm{FA})$

\section{Model specification}

The econometric models employed in this study intend analyze the impact of remittance inflow on Nepalese economy. Linear multiple regression models is used to explain the impact of remittance inflow, broad money supply, foreign aid, capital formation, imports used in this study. Model of this study, which is based on the dependent and independent variables are obtained by the following equation.

\section{Model}

$$
G D P_{i t}=\beta_{0}+\beta_{1} R E M_{i t}+\beta_{2} M S_{i t}+\beta_{3} F A_{i t}+\beta_{4} I M p_{i t}+\beta_{5} C F_{i t}+e \text { it } \ldots \ldots \ldots \ldots \ldots . . .(i)
$$


Vol. 4, No. 1

Where,

$\beta(i=1,2,3,4$, and 5$)=$ Regression parameters

$$
\begin{aligned}
& t=1,2,3,4 \ldots \ldots \ldots \ldots \ldots \ldots \ldots \ldots .22 \\
& \beta_{0}=\text { constant term } \\
& e_{i t} \quad=\text { Error term }
\end{aligned}
$$

GDP it refers to the GDP sample of the study ' $i$ 'for period ' $t$ '.

,PCI: it denotes to the per capita income of the study ' $i$ ' for period ' $t$ '.

,REM: it represent to total income from abroad of the study ' $i$ 'for period ' $t$ '.

MS: it is the broad money supply for the study ' $i$ ' for period ' $t$ '.

FA: it is the foreign aid received by country ' $i$ ' and for period ' $t$ '

IMP: it is the goods imported from abroad in country ' $i$ ' for period ' $t$ '.

$\beta_{0}$ denotes intercept term and $\beta_{1} \beta_{2}, \beta_{3}, \beta_{4}, \beta_{5}$, are the respective parameters (beta coefficients or regression coefficients) of the explanatory variables to be estimated.

\section{Results}

The stated table 1 showed that GDP of Nepal is in increasing trend from the year 1994 to 2017. The gross domestic product of Nepal is highest (NRs.2406.048 billion) in the year 2017 with and the lowest (NRs.219.75 billion) in year 1994. It has been observed that in the year 1997, 1998, 1999, 2000, 2001, 2002, 2003, 2004 and 2005 the gross domestic product of Nepal is NRs. 300.845 billion, NRs. 342.026 billion, NRs. 379.488 billion, NRs. 441.519 billion, NRs. 459.443 billion, NRs.492.231 billion, NRs.536.749 billion, NRs. 589.412 billion and NRs. 654.084 billion respectively.

Table 3 Description of Dependent and Independent Variables

\begin{tabular}{lcl}
\hline Variables & Symbol & Description \\
\hline $\begin{array}{l}\text { Dependent variables } \\
\text { Gross domestic product }\end{array}$ & GDP & Real GDP of the country \\
Per capita income & PCI & Income of individuals within the country. \\
Independent variables & & \\
Remittances inflow & REM & Earnings from abroad employment \\
Broad money supply & MS & $\begin{array}{l}\text { Short-duration deposits and short-term securities } \\
\text { other than shares }\end{array}$ \\
Foreign aid & FA & Assistance provided by another nation \\
Capital formation & CF & Total capital formation growth \\
Import & IMP & Goods imported from abroad. \\
\hline
\end{tabular}


NCC JULRNAL - 2019

Table 4 Pattern and Structure of Gross Domestic Product

Time (1994/95 to 2016/17)

$1994 / 95$

$1995 / 96$

1996/97

$1997 / 98$

1998/99

$1999 / 2000$

$2000 / 01$

$2001 / 02$

$2002 / 03$

2003/04

2004/05

2005/06

2006/07

$2007 / 08$

2008/09

2009/10

2010/11

2011/12

2012/13

2013/14

$2014 / 15$

2015/16

2016/17
GDP(in billion Rupee)

219.75

248.913

280.513

300.845

342.026

379.488

441.519

459.443

492.231

536.749

589.412

654.084

727.827

815.658

988.272

1192.774

1366.954

1527.344

1692.643

1941.624

2120.47

2248.691

2406.048

Source: www.the globaleconomy.com

Likewise, the per capita income of Nepal is the highest in the year 2015 (NRs.85066.8) and lowest in the year 1994 (NRs10500). In the year 2003, 2004, 2005 and 2006 and the per capita income are NRs. 22533, NRs 22351, NRs 24616, NRs 26714, respectively. Similarly, the per capita incomes of a country in the year 2011, 2012, 2013, and 2014 are NRs 61389.3, NRs 71167.7, NRs 75149.96, NRs 77879.32 respectively. Figure 1shows the pattern of gross domestic product for the period 1994/95 to 2016/17. 
Vol. 4 , No. 1

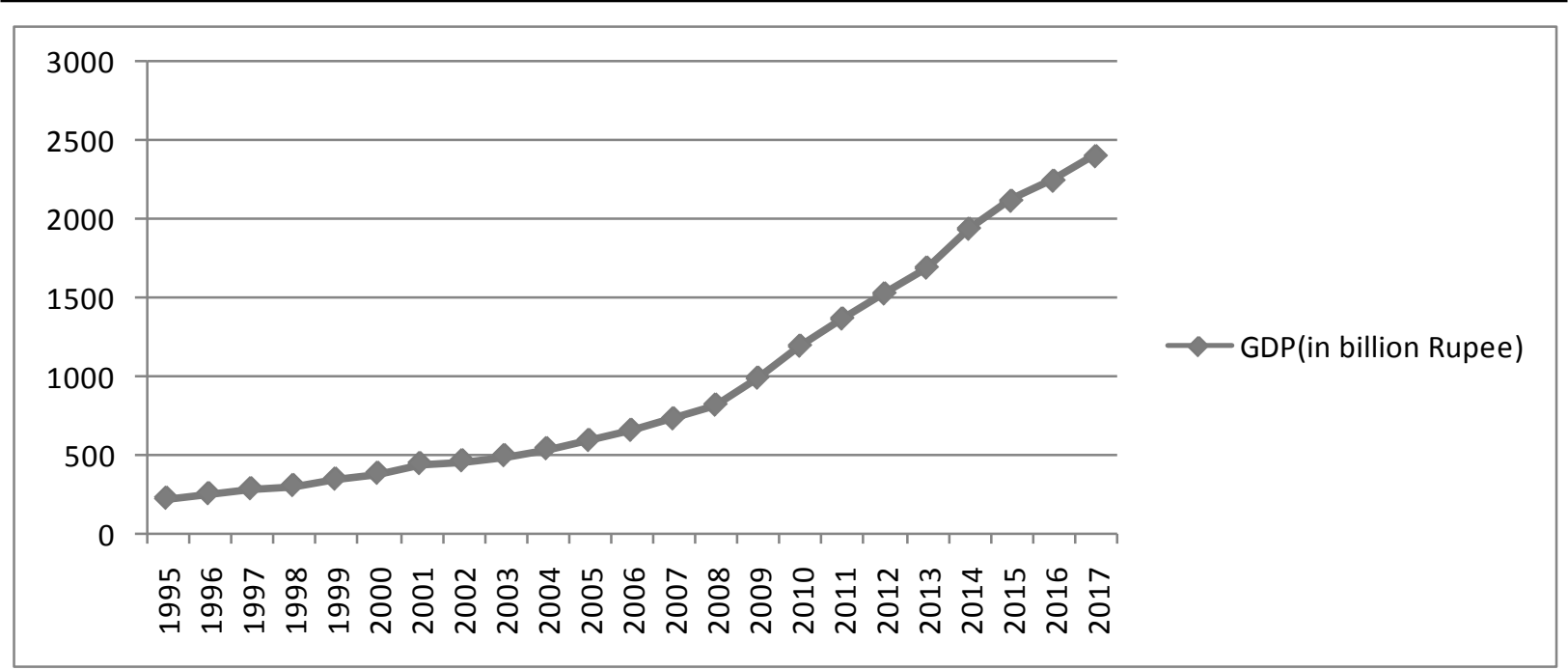

Figure 2 Pattern of GDP (in Billion Rupees)

Figure 2 shows the pattern of gross domestic product ranging from the year 1995 to 2017. The vertical axis (Y-axis) represents the gross domestic product and horizontal axis (X-axis) represents the time duration. It can be observed that gross domestic product is in increasing trend from the year 1995 to 2001 and the gross domestic product is little bit constant in year 2001 and 2004.

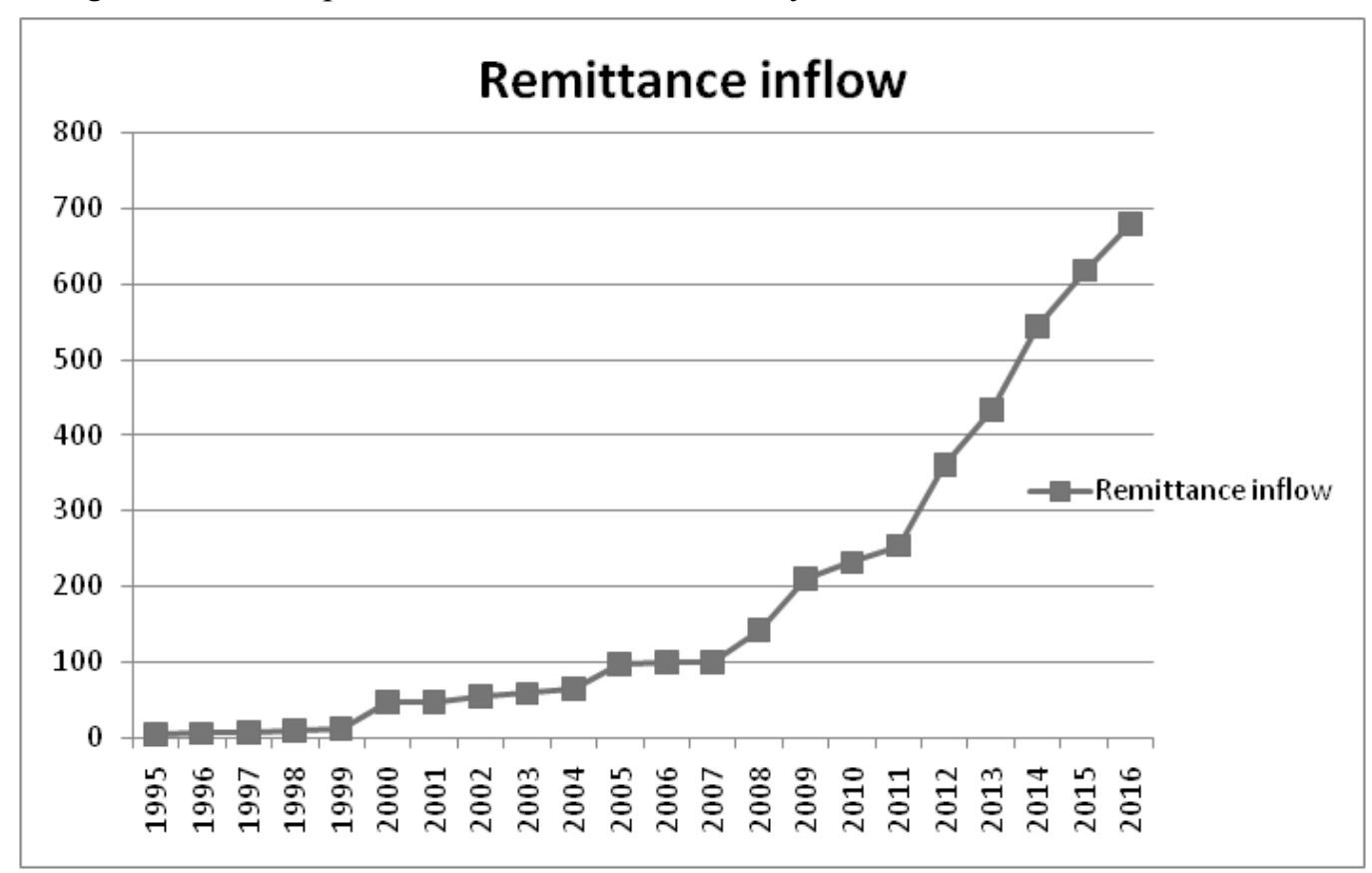

Figure 3 Pattern of total remittances inflows (in Billion Rupees)

Figure 3 shows the pattern of total remittances for the study period of 1995/96 to 2016/17. The vertical axis (Y-axis) represents the total remittances inflows and horizontal axis (X-axis) represents the time duration. The figure shows that total remittance increased from the year 2008 to 2016. The total remittance is stable from the year 2001 to 2005. After 2005, total remittance is in increasing trend. Hence, there has been a large increment in the total remittances inflows in the recent years. 


\section{Regression analysis}

The table shows regression results of variables based on time series data from period of 1995/96 to 2016/17. The regression result consists of specification of the model in the form of simple and multiple regressions. Dependent variable is total GDP and independent variables are REM (remittance defined as earnings from abroad employment, in Billion Rupees), MS (broad money supply defined as short-duration deposits and short-term securities other than shares, in Billion Rupees), FA (foreign aid defined as assistance provided by another nation, in Billion Rupees), CF, (capital formation defined as total capital formation growth in percentage)

$G D P_{i t}=\boldsymbol{\beta}_{0}+\beta_{1} R E M_{i t}+\beta_{2} M S_{i t}+\beta_{3} F A_{i t}+\beta_{4} I M p_{i t}+\beta_{5} C F_{i t}+e i$

Table 5 Regression analysis

\begin{tabular}{|c|c|c|c|c|c|c|c|c|c|}
\hline \multirow{2}{*}{ Model } & \multirow{2}{*}{ Intercepts } & \multicolumn{5}{|c|}{ Regression coefficients of } & \multirow[t]{2}{*}{ Adj- $R^{2}$} & \multirow[t]{2}{*}{ SEE } & \multirow[t]{2}{*}{ F-value } \\
\hline & & REM & MS & FA & IMP & $\mathrm{CF}$ & & & \\
\hline 1 & $\begin{array}{c}322.52 \\
(11.27)^{* *}\end{array}$ & $\begin{array}{c}3.05 \\
(29.53)^{* *}\end{array}$ & & & & & 0.97 & 99.48 & 872.50 \\
\hline 2 & $\begin{array}{c}292.43 \\
(25.52)^{* *}\end{array}$ & & $\begin{array}{c}0.99 \\
(25.52)^{* *}\end{array}$ & & & & 0.96 & 119.24 & 601.23 \\
\hline 3 & $\begin{array}{c}-12.80 \\
(-0.083)\end{array}$ & & & $\begin{array}{c}27.97 \\
(6.75)^{* *}\end{array}$ & & & 0.68 & 366.81 & 45.64 \\
\hline 4 & $\begin{array}{c}127.71 \\
(6.005)^{* *}\end{array}$ & & & & $\begin{array}{c}2.05 \\
(46.50)^{* *}\end{array}$ & & 0.99 & 63.62 & 2.612 \\
\hline 5 & $\begin{array}{c}-1720.92 \\
(-4.20)\end{array}$ & & & & & $\begin{array}{c}90.84 \\
(6.51)^{* *}\end{array}$ & 0.66 & 376.30 & 42.37 \\
\hline 6 & $\begin{array}{c}-220.96 \\
(-1.76)\end{array}$ & & $\begin{array}{c}0.85 \\
(18.56)^{* *}\end{array}$ & & & $\begin{array}{c}20.88 \\
(4.18)^{* *}\end{array}$ & 0.98 & 88.23 & 557.72 \\
\hline 7 & $\begin{array}{l}-30.35 \\
(-0.31)\end{array}$ & & $\begin{array}{c}0.16 \\
(1.089)\end{array}$ & & $\begin{array}{c}1.59 \\
(4.539)^{* *}\end{array}$ & $\begin{array}{c}7.90 \\
(1.75)\end{array}$ & 0.99 & 61.90 & 762.36 \\
\hline 8 & $\begin{array}{c}132.70 \\
(4.41)^{* *}\end{array}$ & & $\begin{array}{c}0.03 \\
(0.24)\end{array}$ & & $\begin{array}{c}1.989 \\
(6.924)^{* *}\end{array}$ & & 0.99 & 65.17 & 1.03 \\
\hline 9 & $\begin{array}{c}1.46 \\
(0.016)\end{array}$ & & & & $\begin{array}{c}1.97 \\
(26.7)^{* *}\end{array}$ & $\begin{array}{c}5.46 \\
(1.38)\end{array}$ & 0.99 & 62.20 & 1.13 \\
\hline 10 & $\begin{array}{c}254.20 \\
(6.09)^{* *}\end{array}$ & $\begin{array}{c}2.78 \\
(17.32)^{* *}\end{array}$ & & $\begin{array}{c}3.69 \\
(2.11)\end{array}$ & & & 0.98 & 91.80 & 514.50 \\
\hline
\end{tabular}

i. Figures in parentheses are t-values.

ii. The asterisk signs (**) and (*) indicate that the results are significant at 1 percent and 5 percent level respectively. iii. Dependent variable is gross domestic product

Having indicated the Pearson's correlation coefficients, the regression analysis has been computed and the results are presented in table 5 More specifically, it shows the regression result of dependent and independent variables for remittance.

Table 5 shows that beta coefficients for total remittance inflow are positive with gross domestic product. It indicates that there is a positive impact of remittance inflow on gross domestic product. This finding is consistent with the findings of Ullahet al., (2015).

Likewise, the result also shows that the beta coefficients for broad money supply and foreign aid have positive impact on gross domestic product It reveals both variables have positive impact on gross 
Vol. 4, No. 1

domestic product. This finding is consistent with the findings of Rao \& Hassan (2012). However, the result reveals that the beta coefficients for capital formation are positive. It indicating that there is positive impact of capital formation on gross domestic product .This finding similar with the findings of akinpelu et al.(2013).

Similarly, the study reveals that beta coefficient for import is positive with gross domestic product. It indicates the import has positive impact to gross domestic product. Likewise, the beta coefficient for foreign aid is positive with gross domestic product. It indicates that foreign aid has positive impact on gross domestic product. This finding is similar to the findings of Pegkas (2015).

\section{Findings}

1. The average gross domestic product of Nepal has been revealed to be NRS. 889.4 billion. The GDP is highest in the year 2016 with NRs. 2406.048 billion and lowest in the year 1994 with NRs. 219.75billion. It shows that GDP of Nepal is in increasing trend from the year 1994 to 2016.

2. The average per capita income of Nepal is NRs.34214.82 with highest (NRs. 85066.8) in year 2016 and lowest (NRs. 10500) in year 1995. The result also indicates that per capita income of Nepal is in increasing trend from year 1995 to 2016.

3. The total remittances inflow of Nepal is highest (NRs. 679 billion) in the year 2016 and lowest (NRs. 4.2836 billion) in the year 1995, leading to an average of NRs. 185.48 billion. The result also indicates that total remittances inflow is in increasing trend from year 1995 to 2016.

4. The Government of Nepal receives an average of NRs. 32.25 billion foreign aid with the highest (NRs. 59.34billion) in year 2009 and lowest (NRs. 5.71 billion) in year 1998.

5. The average broad money supply of Nepal is NRs. 598.62 billion with highest (NRs. 2290.91 billion) in year 2016 and lowest (NRs. 56.18 billion) in year 1994. The result also indicates that broad money supply is in increasing trend from year 1994 to 2015.

6. The average capital formation of Nepal has been revealed to be 28.73 percent which ranges from minimum 20.25 percent to maximum of 38.27 percent.

7. The imports of Nepal is recorded to highest (NRs. 1035.452 billion) in the year 20145and lowest (NRs.87.48438 billion) in year 1994 leading to an average of NRs. 370.3 billion.

8. Gross domestic product is positively related to capital formation. It indicates that higher the gross capital formation, higher would be gross domestic product.

9. Moreover, gross domestic product is positively related to foreign aid. It indicates that increase in foreign aid leads to an increase in GDP.

10. Similarly, the result shows that per capita income is positively related to remittance inflows. It indicates that increase in remittance inflows leads to an increase in per capita income.

11. Likewise, the regression analysis shows that beta coefficients are positive for remittance inflows, consumption, import, gross capital formation and foreign direct investment of per capita GDP.

12. The regression analysis of gross domestic product shows that the beta coefficient are positive for total remittances inflow, broad money supply, foreign aid, imports and capital formation. The result indicates that higher the total remittances inflow, broad money supply, foreign aid, imports and capital formation, higher would be gross domestic product.

13. It is found that per capita income is positively related to capital formation indicates that higher the capital formation, higher would be per capita income.

14. It is also revealed that per capita income is positively related to import indicating that higher the import, higher would be per capita income.

15. The beta coefficient for total remittance inflow is positive and significant at 1 percent level of significance. Thus, the result indicates that higher the total remittances inflow, higher would be the gross domestic product. Similarly, the broad money supply, foreign aid, imports and capital formation are significant at 1 percent level of significance. 
16. The regression result for the dependent variables of per capita income shows that the beta coefficients is positive for total remittances inflow, broad money supply, foreign aid, imports and capital formation. The result indicates that higher the total remittances inflow, broad money supply, foreign aid, imports and capital formation, higher would be per capita income.

17. The beta coefficient for remittance inflow is positive and significant at 1 percentage level of significance.

Thus, remittance inflows to Nepalese economy have positive impacts on economy. Thus, the benefits associated with remittances inflow have multiplier effects driving the whole economy towards growth as remittance fuel up growth for other sectors like consumption, education, employment etc. However, still there are various cons associated with remittance economy.

\section{Conclusions}

The major conclusion of this study is that the total remittance inflow affects the economic growth of Nepal. Remittance inflows, broad money supply, capital formation in the country, demand for imported goods and foreign aid have positive impact on GDP and per capita income of Nepal. It indicates that higher the remittance inflows, broad money supply, import, foreign aid and capital formation, higher would be gross domestic product and per capita income. The study also concludes that remittance is the most significant sources of GDP and per capita income in Nepal. It plays a prominent role in the economy of the nation as they are the major sources of income for most of the household consumption in the country also remittances have stimulated in the development of nation. Similarly, the study concludes that higher the remittance inflows, foreign aid, capital information, import and broad money supply, better would be the economic growth of the nation.

\section{Policy Implication}

This study contributes to planners, researchers for further study on remittance and its impact on GDP of a country and the government to formulate appropriate economic policies. This study can be extended in the future including more variables.

\section{References}

Anzoategui, D., Demirgüç-Kunt, A., \& Pería, M. S. (2011). Remittances and fina inclusion: Evidence from El Salvador. World Development, 54(1), 338-349.

Barajas, A., Gapen, M. T., Chami, R., Montiel, P., \& Fullenkamp, C. (2009). Do worker's remittance promote economic growth ? IMF staff paper, 52 (1), 55-82.

Bhatta, G. R. (2013). Remittance and trade deficit nexus in Nepal: A VECM approach. NRB Working Paper No. 14 .

Burgess, R., \& Haksar, V. (2005). Migration and foreign remittance in the phillipines:. 1-17.

Fayissa, ,. B., \& Nsiah, C. (2010). The impact of remittance on economic growth and development in Africa. 55 (2), 92-100.

Fayissa, B., \& Nsiah, c. (n.d.). impact of remittance on economic growth and development in Africa. department of economics and finance working paper series .

Gaudel, Y. S. (2006). Remittance Income in Nepal. Nepalese Business Studies , 3 (1), 9-17.

Giuliano, ,. p., \& arranz, ,. M. (2006). Remittance,financial development and growth.

Giuliano, P., \& Arranz, M. R. (2005). Remittance,financial development andgrowth. 
Vol. 4, No. 1

IMF. (2005). world economic outlook. international monetary Fund.

IMF, I. M. (2009). Balance of payment and international investment position manual.

Imai, K. S., Gaiha, R., Ali, A., \& Kaicker, N. (2011). Remittances, growth and poverty: New evidence from Asian countries. RIEB Discussion Paper Series No. 30 , 1-35.

Jawaid, S. T., \& Raza, S. A. (2012). Remittances, growth and convergence:.

Kafle, J. (2014). Effects of remittances on economic growth and financial sector development in Nepal. Nepalese Journal of Management, 1(1), 1-96.

Khan, A. (2011). Workers' Remittances and Economic Growth:.

Khathlan, K. A. (2012). The link between remittances and economic growth in Pakistan: . Economic, Management and Trade, , 2 (3), 167-185.

Kollmair, M., Manandhar, S., Subedi, B., \& Thieme, S. (2006). New figures for old stories: Migration and remittances in Nepal. 3 (2), 151-160.

Kumar, R. R. (2010). Growth and remittance nexus in the fiji Islands: An investigation using bounds test analysis. University of South Pasific, 1-21.

Malekoo, R. (2015). Impact of remittance on deposit of commercial banks' and economic growth of Nepal. MBA Dessertation, 1-76.

Mundaca, B. G. (2011). Remittance,financial market development and economic growth. Review of development economics , 13 (2), 288-303.

Mundaca, B. G. (2009). Remittance,financial market development,and ecnomic growth. 13 (2), 288-303.

Nepal Rastra Bank. (2016). Economic Survey. Nepal Rastra Bank.

Neupane, N. K. (2011). An analysis of impact of remittance on Nepalese economy. A Dissertation , 1-100.

Pant. (2011). Harnessing Remittances for Productive Use in Nepal. Economic Review , 1-20.

Pant. (2006). Remittance Inflows to Nepal. 20-36.

Pant, B. (2011). Harnessing Remittances for Productive Use in Nepal. 1-20.

Pradhan, G., Upadhyay, M., \& Upadhyay, K. (2008). Remittances and developing countries. Development Research , 20 (3), 497-506.

Pradhan, G., Upadyaya, M., \& Upadyaya, K. (2008). Remittance and economic growth in Developing countries. Development Research , 20 (3), 497-506.

Rajan, ,. R. (2005). Financing development in the Asia and pacific region. 55 (1), 1-52.

Salahuddin, M., \& Gow, J. (2015). The relationship between economic growth and remittances in the presence of cross-sectional dependence. Developing Areas , 49 (1), 1-15.

Shafqat, M. M., Ahmad, A., \& Bano, S. (2014). Impact of worker's remittance on economic growth of pakistan:. BUsiness research Turk, 6 (2), 1-14.

Shrestha, B. (2008). Contribution of foreign employment and remittance to Nepalese economy. 20 (1), $1-15$.

Spatafora, N. (2005). Two current issue facing developing countries.

Srivastava, N. L., \& Chaudary, S. K. (2007). Role of remittances in economic development of Nepal. Nepalese Business Studies , 4 (1), 28-37. 
stahl, C. (2008). Labor emigration and economic development. Economics and financial, 868-899.

Thagunna, K. S., \& Acharya, S. (2013). Empirical analysis of remittance inflow. Economics and Financial Issues , 3 (2), 337-344.

Thagunna, K. S., \& Acharya, S. (2013). Empirical analysis of remittance inflow:. Economics and Financial Issues , 3 (2), 337-344.

Vargas-silva, ,. C. (2008). Remittances in Asia: Implications fo the fight against poverty and the pursuit of economic growth. 19, 290-303.

Vargas-silva, C., Jha, S., \& Sugiyarto, G. (2009). Remittance in Asia:. 1-28.

Yang, D. (2008). International migrattion, remittance and household investment. The economic journal , 1 (5), 591-630.

Yaseen, H. S. (2012). The positive and negative impact of remittances on economic growth in MENA countries. Journal of International Management Studies, 7(1), 7-21.

Web Link: http:// http://data.worldbank.org/data-catalog/world-development-indicators https://asiafoundation.org/resources/pdfs/MigrationReportbyGovernmentofNepal.pdf 